\title{
Correlation Between Nitrogen Dioxide as an Air Pollution Indicator and Breast Cancer: a Systematic Review and Meta- Analysis
}

\author{
Aliasghar Keramatinia', Soheil Hassanipour², Milad Nazarzadeh³, Morten \\ Wurtz $^{4}$, Ayad Bahadori Monfared ${ }^{5}$, Maryam Khayyamzadeh${ }^{1}$, Zeinab Bidel ${ }^{3}$, \\ Narges Mhrvar ${ }^{1}$, Alireza Mosavi-Jarrahi ${ }^{5,3,6 *}$
}

\begin{abstract}
Background: The aim of this systematic review was to study the relationship between exposure to nitrogen dioxide $\left(\mathrm{NO}_{2}\right)$ in the ambient air and breast cancer incidence. Materials and Methods: A systematic review was performed based on the MOOSE guideline for review of observational studies. We searched five online databases (PubMed, Science Direct, Google Scholar, EBSCO, and Scopus) from their conception to June 2014. A pooled estimate of the correlation between $\mathrm{NO}_{2}$ exposure and breast cancer incidence was calculated using Pearson's correlation coefficient. Results: A total of 654 titles were retrieved in the initial search of the databases. Further refinement and screening of the retrieved studies produced a total of five studies from four countries. The studies included three ecological studies (aggregate level) and two individual based studies (one prospective cohort and the other one a case-control study). The ecological studies were pooled and the meta-analysis of correlation coefficient without $\mathrm{z}$ transformation showed a pooled estimate of $\mathrm{r}=0.89$ with $95 \%$ CI of 0.84 to 0.95 . Using $\mathrm{z}$ transformation, the pooled $r$ was 1.38 with $95 \% \mathrm{CI}$ of 1.11 to 1.59. No significant heterogeneity between studies was observed. Following a sensitivity analysis and the removal of each study from pooled analysis we did not see any significant change in the pooled estimate. Conclusions: It was concluded that there is a tendency toward a weak association between exposure to $\mathrm{NO}_{2}$ in ambient air and breast cancer at the individual level and a significant association at the aggregate level.
\end{abstract}

Keywords: Breast cancer - air pollution - nitrogen dioxide - meta-analysis

Asian Pac J Cancer Prev, 17 (1), 419-424

\section{Introduction}

Breast cancer is a leading cause of mortality and morbidity all over the world. In 2008, close to 1.4 million cases were diagnosed with breast cancer worldwide (Ferlay et al., 2007). The breast cancer incidence displays great geographical variation with higher rates in developed countries compared to developing countries (Youlden et al., 2012; Bray et al., 2013). In general, breast cancer rates are highest in white European and lowest in East Asian populations (Ferlay et al., 2007; Hirabayashi and Marugame, 2009; Cho et al., 2010), regions of world with different pattern of industrialization. The estimated incidence rate for women living in the South-East Asia region of World Health Organization' is 26.1 per 100,000 population and this figure is 89.7 for women living in
Western Europe (Ferlay et al., 2007).

A high risk of breast cancer has been associated with a combination of Western lifestyle characteristics, including early menarche, decreased parity, delayed childbearing, and a sedentary lifestyle as well as exposure to environmental carcinogens (Gerber et al., 2003; McTiernan, 2003). Studies of migrants have confirmed the major contribution of environmental and lifestyle factors in the etiology of breast cancer (Tsugane et al., 1990; Shimizu et al., 1991; Iwasaki et al., 2008). Since the pattern and magnitude of established risk factors in different part of the world cannot explain the variation seen in the magnitude and trends in incidence of breast cancer, recent studies has focused on the role of ambient environmental carcinogens in etiology of breast cancer.

The long and short term exposure to air pollution has

${ }^{1}$ Cancer Research Center, Shahid Beheshti University of Medical Sciences, ${ }^{2}$ Department of Epidemiology and Biostatistics, School of Public Health and Health Care Research Institute, Tehran University of Medical Sciences, ${ }^{3}$ Iranian Research Center on Healthy Aging, Sabzevar University of Medical Sciences, ${ }^{5}$ Department of Social Medicine, Medical School, Shahid Beheshti University of Medical Sciences, Tehran, Iran, ${ }^{4}$ Department of Cardiology, Aarhus University Hospital, Aarhus, Denmark, ${ }^{6}$ Faculty of Health Sciences, Simon Fraser University, B.C., Canada*For correspondence: rmosavi@yahoo.com 
Aliasghar Keramatinia et al

been demonstrated to contribute to incidence and mortality for many diseases. It is almost established that air pollution causes lung cancer (Hamra et al., 2014) and the causal effect of air pollution has been suspected for cancers of blood (Tong et al., 2012; Boothe et al., 2014), bladder (Castano et al., 2008), cervical cancer (Raaschou et al., 2011a), prostate (Parent et al., 2013), brain (Raaschou et al., 2011a), and breast (Chen and Bina, 2012b). Several studies have reported higher mortality rates for breast cancer in areas with a high degree of air pollution (Chen and Bina, 2012a; Wei et al., 2012; Al-Ahmadi and AlZahrani, 2013). In Europe and the United States, it has been shown that the incidence of breast cancer follows the variations in air pollution patterns with a delay of 20 years (Chen and Bina, 2012b).

The air pollution contains gaseous and solid particles. The main gaseous compounds are nitrogen oxides (NOx), carbon oxides (COx), sulfur oxides (SOx) and the solid particles include particulate matter with diameters of less than $10 \mu \mathrm{m}$ (PM10). Many of these compounds either solid or gas have been proven to be either mutagenic or carcinogenic and can cause cancer (Lewtas, 2007).Among the many chemical component of air pollution suspected in the etiology of breast cancer, NOx has received special attention due to $i$ ). the involvement of NOx and its by products such as $\mathrm{N}_{2} \mathrm{O}_{3}$ in cytotoxicity and DNA adduct (Lewtas, 2007), ii). internally generated NOx activity has been detected in tumor cells of various histological origins and has been associated with tumor grade, proliferation rate and expression of important signaling components associated with cancer development such as estrogen, iii). NOx is very specific to air pollution make it a reliable proxy candidate for assessment of exposure to air pollution (Chen and Bina, 2012b). The specificity of nitrogen dioxide $\left(\mathrm{NO}_{2}\right)$ as a proxy indicator of exposure to air pollution and the suspected causal effect of $\mathrm{NO}_{2}$ in the etiology of breast cancer have made this indicator of exposure a subject of many research and epidemiologic studies relating air pollution and breast cancer.

The knowledge about the association between $\mathrm{NO}_{2}$ and large number of non-respiratory disease such as breast cancer is limited. We therefore systematically reviewed all epidemiologic studies examining the relationship between $\mathrm{NO}_{2}$ as an indicator of exposure to air pollution and breast cancer incidence in order to address the relationship between breast cancer and air pollution.

\section{Materials and Methods}

Inclusion and exclusion criteria and review guideline

The systematic review was undertaken based on the MOOSE guideline for review of observational studies (Stroup et al., 2000). Inclusion criteria included any observational study or field trial that reported any measure of association between $\mathrm{NO}_{2}$ exposure and breast cancer. Experimental or laboratory studies, interventional studies that the outcome come did not include breast cancer, studies of air pollution without referring specifically to $\mathrm{NO}_{2}$ exposure or breast cancer as outcome, review article and meta-analysis were excluded.

\section{Search strategy}

We searched 5 online databases (PubMed, Science Direct, Google Scholar, EBSCO, and Scopus) from their conception to June 2014. The search strategy included the main component of inclusion criteria. Each component's main term and their synonyms were searched both free and $\mathrm{MeSH}$ indexing term as follow: air pollution or synonyms: air pollution, ozone, carbon monoxide, nitrate oxide, sulfur dioxide, and particulate matter; nitrogen or synonyms: $\mathrm{NO}_{2}$, nitrogen dioxide, deutoxide of nitrogen, nitrogen (IV) oxide, nitrogen oxide, NOx, and NO; breast cancer or synonyms: breast neoplasms, breast tumor, human mammary neoplasm, human mammary carcinoma, cancer of breast, breast cancer, mammary cancer, malignant neoplasm of breast, malignant tumor of breast, breast carcinoma, cancer of the breast, ductal carcinoma of breast, lobular carcinoma of breast, medullary breast cancer, breast tumor, and in situ breast cancer. Reference lists of all included studies and recent reviews were manually inspected. The search was limited to the English language. The EndNote software (version $\mathrm{X} 4$ ) was employed to search and to import citations from the databases.

\section{Study selection}

Two reviewers independently scanned the titles of all retrieved citations, removing duplicate and identifying potentially relevant abstracts for further inclusion. Selected abstracts were independently reviewed by two researchers for further relevancy and refinement. If there were any disagreement between reviewers in abstract relevancy, a third researcher acted as a mediator. Figure 1 show the details related to the selection process of studies for two reviewers.

\section{Data extraction}

For each selected study the following data or items of information were abstracted and tabulated for further analysis: first author identifier; date of publication; date

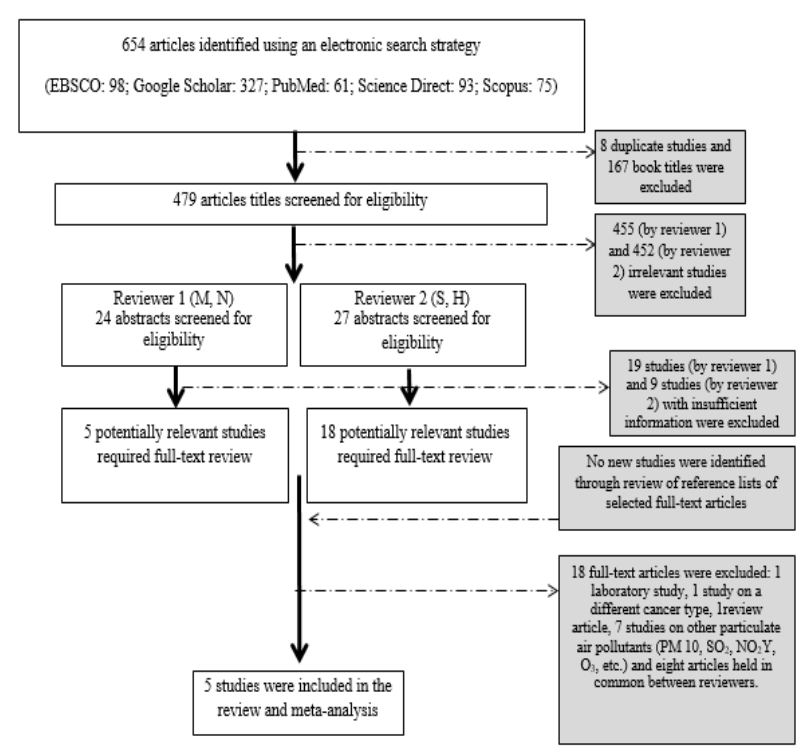

Figure 1. Flowchart of the Reviewing Process of Studies Associating $\mathrm{NO}_{2}$ with Breast Cancer 
of conduction; country of origin; age range of subjects or its mean (if any); study participants (defined by country of origin or ethnic sub population inside a country if exist), study setting, study design, the statistical methods used, length of study, outcome definition, exposure definition, measure of association and its $95 \%$ confidence interval (95\% CI) and confounding factor consideration.

\section{Statistical analysis}

A pooled estimate was calculated only for Pearson's correlation coefficient ( $\mathrm{r}$ ) correlating exposure to $\mathrm{NO}_{2}$ and incidence of breast cancer. For uniformity, all confidence intervals (CIs) were calculated using the Fisher's r-to-z transformation. Using this transformation, we converted $\mathrm{r}$ (correlation coefficient) to $\mathrm{z}$ (normal distribution) to obtain approximate normality and then calculated the mean and standard errors of the transformed correlation, which were weighted to the sample sizes in these studies (Chen and Wang, 2008; Donner and Rosner, 1980). The pooled estimates were reported both with and without $\mathrm{z}$ transformation. The presence of heterogeneity was assessed by Cochran's Q statistic (with a significance level of $\mathrm{p} \leq 0.1$ ) combined with $\mathrm{I} 2$ statistic (with a significance level of $>50 \%$ ). In presence of significant heterogeneity ( $\mathrm{p} \leq 0.1$ and $\mathrm{I} 2 \geq 50 \%$ ), random effect model (with inverse variance method) were used for calculation of pooled $r$, and if there were no evidence of heterogeneity $(\mathrm{p}>0.1$ and $\mathrm{I} 2<50 \%$ ) fixed effect model were employed. All analyses were conducted using Stata version 11.2 (Stata Corp LP, College Station, Texas).

\section{Results}

A total of 654 articles were retrieved, of which five studies were eligible for inclusion (Crouse et al., 2010; Raaschou-Nielsen et al., 2011b; Chen and Bina, 2012a; Wei et al., 2012; Al-Ahmadi and Al-Zahrani, 2013). The main and methodological characteristics of each paper are shown in Tables 1 and 2. The studies included three

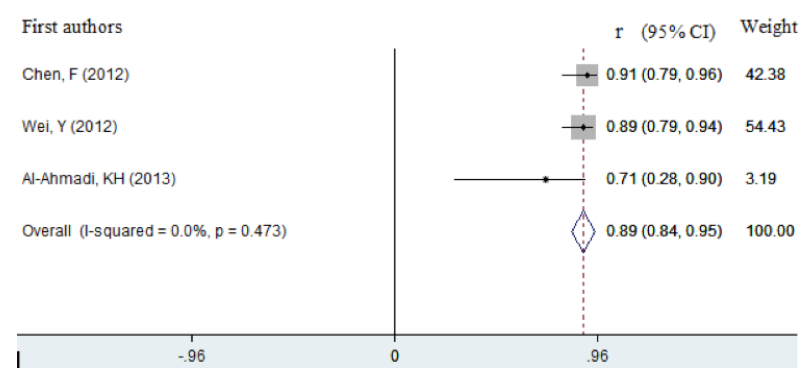

Figure 2. Forest Plot of Studies Related $\mathrm{NO}_{2}$ to Breast

Cancer. Rectangles indicate Pearson's correlation coefficient (r) and the size of the rectangles represents the weight given to each study in the analysis; diamonds and the vertical dashed line indicate the combined $r$, and horizontal lines indicate 95\% confidence intervals

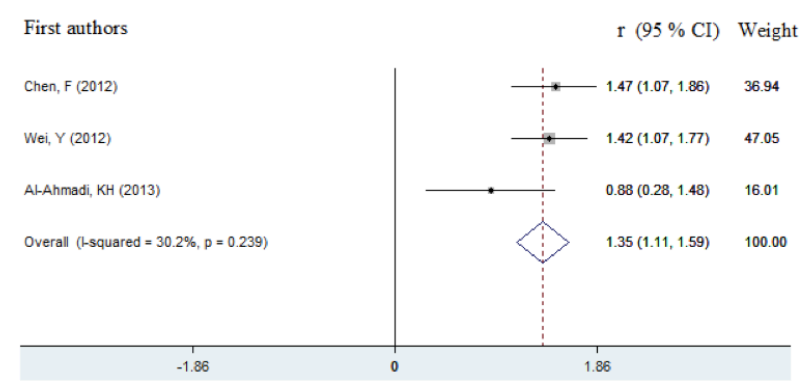

Figure 3. Forest Plot of Studies Relating $\mathrm{NO}_{2}$ to Breast Cancer. Rectangles indicate Pearson's correlation coefficient (r) with z transformation. After turning $\mathrm{z}$-transformed $\mathrm{r}$ to initial $r$, the pooled estimate was $r=0.87$ ( $95 \%$ CI 0.80 to 0.92 ). The size of the rectangles represents the weight given to each study in the analysis; diamonds and the vertical dashed line indicate the combined $r$, and horizontal lines indicate $95 \%$ confidence intervals

Table 1. Characteristics of the Five Studies Included in the Final Stage of the Systematic Review Exploring the Association Between $\mathrm{NO}_{2}$ Exposure and Breast Cancer

\begin{tabular}{|c|c|c|c|c|c|c|}
\hline First author & $\begin{array}{c}\text { Date of } \\
\text { publication }\end{array}$ & $\begin{array}{c}\text { Date of } \\
\text { performance }\end{array}$ & Country & $\begin{array}{l}\text { Age } \\
\text { (range) }\end{array}$ & Participants & Setting \\
\hline Al-Ahmadi, KH & 2013 & 1998 to 2006 & $\begin{array}{l}\text { Saudi } \\
\text { Arabia }\end{array}$ & NM & $\begin{array}{l}\text { Women with } \\
\text { breast cancer }\end{array}$ & $\begin{array}{c}\text { Saudi Arabian Cancer } \\
\text { Registry }\end{array}$ \\
\hline Chen, F & 2012 & 1973 to 2007 & U.S. & NM & $\begin{array}{c}\text { White women } \\
\text { with breast cancer }\end{array}$ & $\begin{array}{c}\text { U.S National Cancer } \\
\text { Institute; U.S } \\
\text { Environmental Protection } \\
\text { Agency }\end{array}$ \\
\hline Wei, Y & 2012 & 1973 to 2007 & U.S. & NM & $\begin{array}{l}\text { Women with } \\
\text { breast cancer }\end{array}$ & $\begin{array}{c}\text { U.S National Cancer } \\
\text { Institute; U.S } \\
\text { Environmental Protection } \\
\text { Agency }\end{array}$ \\
\hline Rassscho-Nielsen, O & 2011 & 1993 to 2006 & Denmark & $50-64$ & $\begin{array}{l}\text { Copenhagen and } \\
\text { Aarhus, general } \\
\text { population }\end{array}$ & $\begin{array}{c}\text { Danish Cancer Registry; } \\
\text { Danish Diet Cancer and } \\
\text { Health cohort }\end{array}$ \\
\hline Crouse, D & 2010 & 1996 to 2006 & Canada & $50-75$ & $\begin{array}{l}\text { Women with } \\
\text { postmenopausal } \\
\text { breast cancer }\end{array}$ & $\begin{array}{l}\text { Cases were identified } \\
\text { from all } 18 \text { hospitals in } \\
\text { the region that treated } \\
\text { breast cancer }\end{array}$ \\
\hline
\end{tabular}

NM: Not mentioned; U.S: United states 
Table 2. Methodological Characteristics of the Five Studies Included in the Final Stage of the Systematic Review Exploring the Association Between $\mathrm{NO}_{2}$ and Breast Cancer

\begin{tabular}{|c|c|c|c|c|c|c|c|}
\hline $\begin{array}{l}\text { First } \\
\text { author }\end{array}$ & $\begin{array}{l}\text { Study } \\
\text { design }\end{array}$ & $\begin{array}{l}\text { Statistical } \\
\text { methods }\end{array}$ & Outcome & Exposure & $\begin{array}{l}\text { Diagnosis } \\
\text { verification } \\
\text { method of } \\
\text { exposure and } \\
\text { outcome } \\
\end{array}$ & $\begin{array}{c}\text { Measure of } \\
\text { association } \\
(95 \% \mathrm{CI})\end{array}$ & Considered confounders \\
\hline Chen & $\begin{array}{l}\text { Eco- } \\
\text { logical }\end{array}$ & $\begin{array}{l}\text { Reg- } \\
\text { ression } \\
\text { analysis } \\
\text { (log- } \\
\text { linear); } \\
\text { Pearson's } \\
\text { cor- } \\
\text { relation }\end{array}$ & $\begin{array}{l}\text { Breast } \\
\text { cancer } \\
\text { (Age } \\
\text { adjusted } \\
\text { inc- } \\
\text { idence } \\
\text { rate) }\end{array}$ & $\begin{array}{l}\text { Air pollution } \\
\text { and motor } \\
\text { vehicle } \\
\text { density ( } \mathrm{NO}_{2} \\
\text { as index) } 30 \\
\text { years before } \\
\text { cancer } \\
\text { diagnosis }\end{array}$ & $\begin{array}{l}\mathrm{NO}_{2} \\
\text { concentrations } \\
\text { reported from } \\
75 \text { monitoring } \\
\text { sites, USA }\end{array}$ & $\begin{array}{c}\mathrm{r}=0.91 \text { (linear } \\
\text { relationship) }\end{array}$ & Race (only white female) \\
\hline Wei & $\begin{array}{l}\text { Eco- } \\
\text { logical }\end{array}$ & $\begin{array}{l}\text { Pearson's } \\
\text { cor- } \\
\text { relation; } \\
\text { linear } \\
\text { reg-ression } \\
\text { analysis }\end{array}$ & $\begin{array}{c}\text { Breast } \\
\text { cancer } \\
\text { incidence } \\
\text { rate }\end{array}$ & $\begin{array}{c}\text { Nitrogen ox- } \\
\text { ides (NOx) } \\
\text { emission } \\
\text { (millions } \\
\text { of tons per } \\
\text { year) }\end{array}$ & $\begin{array}{l}\text { Emission } \\
\text { data of five } \\
\text { criteria of air } \\
\text { pollutants } \\
\text { were published } \\
\text { from years } \\
1940-2008\end{array}$ & $r=0.89$ & - \\
\hline $\begin{array}{l}\text { Rassscho } \\
\text {-Nielsen }\end{array}$ & Cohort & $\begin{array}{l}\text { Cox } \\
\text { proport- } \\
\text { ional } \\
\text { hazard } \\
\text { regression } \\
\text { models }\end{array}$ & $\begin{array}{l}\text { Breast } \\
\text { cancer }\end{array}$ & $\begin{array}{l}\text { Air pollution } \\
\text { from traffic }\end{array}$ & $\begin{array}{l}\text { Outcome } \\
\text { committee }\end{array}$ & $\begin{array}{c}\text { IRRb crude } \\
=1.39(1.09 \\
\text { to } 1.77) \text { IRR } \\
\text { adjusted = } \\
1.16(0.89 \text { to } \\
1.51)\end{array}$ & $\begin{array}{l}\text { Body mass index, education level, } \\
\text { alcohol consumption, child births } \\
\text { (number and age at first), lactation, } \\
\text { hormone replacement therapy, benign } \\
\text { breast disease, physical activity level, } \\
\text { occupation }\end{array}$ \\
\hline $\begin{array}{l}\text { Al-Ah- } \\
\text { madi }\end{array}$ & $\begin{array}{l}\text { Eco- } \\
\text { logical }\end{array}$ & $\begin{array}{l}\text { Ordinary } \\
\text { Least } \\
\text { Square } \\
\text { (OLS); } \\
\text { Geo- } \\
\text { graphic } \\
\text { Weighted } \\
\text { Reg- } \\
\text { ression } \\
\text { (GWR) }\end{array}$ & $\begin{array}{c}\text { Breast } \\
\text { cancer } \\
\text { incidence } \\
\text { rate }\end{array}$ & $\begin{array}{l}\text { Air pollution } \\
\qquad\left(\mathrm{NO}_{2}\right)\end{array}$ & $\begin{array}{c}\text { A global } \mathrm{NO}_{2} \\
\text { pollution map } \\
\text { produced by } \\
\text { the Satellite } \\
\text { Group in the } \\
\text { Max-Planck- } \\
\text { Institute for } \\
\text { Chemistry } \\
\text { in Mainz, } \\
\text { Germany }\end{array}$ & $\begin{array}{c}\text { Association } \\
\text { between } \mathrm{NO}_{2} \\
\text { and breast } \\
\text { cancer at the } \\
\text { regional level } \\
\mathrm{R}=0.71 \\
\text { Association } \\
\text { between } \mathrm{NO}_{2} \\
\text { and breast } \\
\text { cancer at the } \\
\text { governorate } \\
\text { level. } \mathrm{r}=0.57 \\
\text { Association } \\
\text { between } \mathrm{NO}_{2} \\
\text { and breast } \\
\text { cancer at the } \\
\text { city level } \mathrm{r}= \\
0.44\end{array}$ & - \\
\hline Crouse & $\begin{array}{l}\text { Case- } \\
\text { con- } \\
\text { trol }^{\text {a }}\end{array}$ & $\begin{array}{l}\text { Uncondi- } \\
\text { tional } \\
\text { logistic } \\
\text { regression } \\
\text { to estimate } \\
\text { ORs }\end{array}$ & $\begin{array}{l}\text { Post- } \\
\text { meno- } \\
\text { pausal } \\
\text { breast } \\
\text { cancer }\end{array}$ & $\begin{array}{l}\text { Traffic- } \\
\text { related air } \\
\text { pollution }\end{array}$ & - & $\begin{array}{c}\mathrm{OR}= \\
1.31(1.00 \text { to } \\
1.71)\end{array}$ & $\begin{array}{l}\text { Adjusted for hospital of diagnosis, } \\
\text { history of breast cancer in mother } \\
\text { and sister, oophorectomy, educational } \\
\text { level, ethnicity, age at menarche, age } \\
\text { at first full-term pregnancy, breast- } \\
\text { feeding history, oral contraceptive } \\
\text { use, hormone replacement therapy, } \\
\text { body mass index, exposure to tobacco } \\
\text { smoke, respondent/proxy status, } \\
\text { alcohol consumption, history of benign } \\
\text { breast disease, and occupational } \\
\text { exposures to solvents with reactive } \\
\text { metabolites, extremely low magnetic } \\
\text { fields, carbon monoxide, and PAHs; } \\
\text { and two neighborhood ecologic } \\
\text { covariates: median household income } \\
\text { and percentage of adults without a high } \\
\text { school diploma }\end{array}$ \\
\hline
\end{tabular}

PAH: Polycyclic aromatic hydrocarbons; a. Case-control study with hospital-based control group; b. Incidence rate ratio

ecological studies, one prospective cohort study, and one case-control study. The case-control study was conducted in Canada with a hospital-based control selection method and showed a significant odds ratio (OR) of 1.31 (95\% 


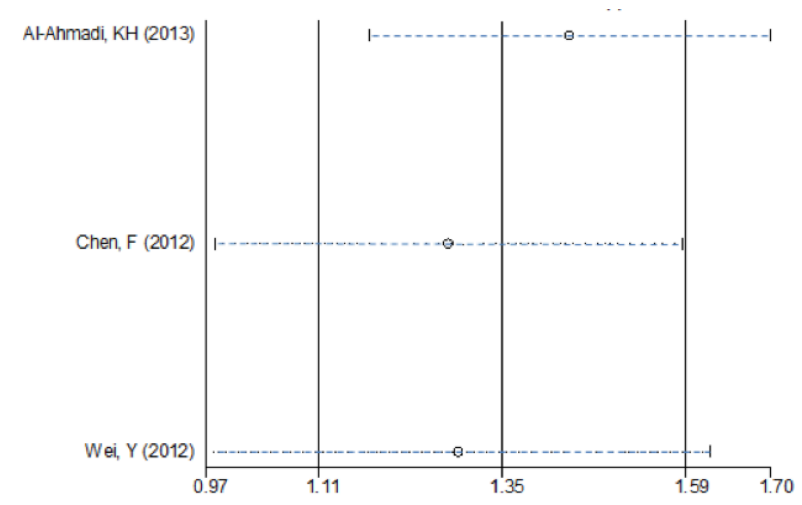

Figure 4. Sensitivity analysis of Studies Relating $\mathrm{NO}_{2}$ to Breast Cancer. Dashed lines in front of first authors indicate 95\% confidence interval after removal of that study from the meta-analysis, and each circle in the middle of the dashed lines indicate point estimates of correlation coefficients (r) after exclusion of that study

CI 1.00 to 1.71$)$. The cohort study was conducted in Denmark with 13 years of follow-up and showed an adjusted incidence rate ratio (IRR) of 1.16 (95\% CI 0.89 to 1.51). The other three studies were ecological studies and reported strong linear correlations between $\mathrm{NO}_{2}$ exposure and breast cancer incidence.

When estimating a pooled correlation coefficient associating $\mathrm{NO}_{2}$ exposure and breast cancer incidence, no significant heterogeneity between studies was observed. Therefore, the fixed effect model was employed for the meta-analysis. Meta-analysis of r's without $\mathrm{z}$ transformation showed pooled $\mathrm{r}=0.89$ (95\% CI 0.84 to $0.95)$ and with $\mathrm{z}$ transformation 1.38 (95\% CI 1.11 to 1.59) that after turning $z$-transformed $r$ to initial $r$, pooled estimation and $95 \%$ CI were 0.87 (0.80 to 0.92). Forest plots of each estimation are shown in Figures 2 and 3. Following a sensitivity analysis and the stepwise removal of each study from the pooled analysis, we did not observe any significant changes in the pooled estimate (Figure 4).

\section{Discussion}

This review showed a tendency toward a weak association between exposure to $\mathrm{NO}_{2}$ and breast cancer at individual level and a significant association at aggregate level. This is the first systematic review and meta-analysis examining the association between $\mathrm{NO}_{2}$ (as either a proxy for air pollution or a suspected etiologic factor) and breast cancer. Consistent with our result, Hung et al. demonstrated that mortality from breast cancer in Taiwan correlated with PM10 and PM5 suggesting that polycyclic aromatic hydrocarbons (PAH) contained in PM2.5 as carcinogen for breast cancer (Hung et al., 2012). Bonner et al., conducted a population based case-control study and showed that early life exposure to particulate matter increased risk of breast cancer for 2.42 times (Bonner et al., 2005).

Although the biologic plausibility for involvement of exogenous $\mathrm{NO}$ in the biology of breast tumor is not established but the endogenous NO at molecular level plays an important role in the biology of cancer. studies of laboratory animal have reported that endogenous NO has an important effect on the promotional phase of neoplastic transformation of C3H 10T1/2 mouse fibroblasts cells plus higher level of NO at the cellular level has cytotoxic effect on tumors cell and low level promote tumors growth $(\mathrm{Xu}$ et al., 2002). In addition, the suppression of DNA repairing system had been attributed to peroxynitrite and NO both in vivo and vitro (Wink and Laval, 1994). So far, the best plausible biologic mechanism of $\mathrm{NO}_{2}$ carcinogenicity for breast cancer would be the role that $\mathrm{NO}_{2}$ can play in DNA adduct and DNA damage.

The association seen in our pooled correlation coefficient may be seen as an indication that exposure to NO can be causally related to breast malignancy however as the correlation is a measure association at the aggregate level, it is subject to serious ecological fallacy (the fallacy that originate from the generalization of aggregate level to individual). Therefore, using methods based on geographic information systems, biomarkers and modelling to improve precision of exposure measurement are warranted.

Our study bears some limitations that include 1) No enough study with adjusted measure of association at the individual level. Although, the two individual based studies indicated a tendency toward positive association 2) The studies included in the meta-analysis were ecological studies with correlation coefficient as measure of association, consequently, the association may not state any risk at individual level, 3) our searched databases did not include the gray literature where we could have found more individual based studies and hence improving our review.

The $\mathrm{NO}_{2}$ density is positively correlated with breast cancer incidence rates in aggregate level. This correlation generates a hypothesis that breast cancer is associated with exposure to NO compounds in ambient air either as an indicator of air pollution or NO as a causative agent contributing to breast cancer malignancy. Further studies at the individual level specifically longitudinal cohort and case-controls are needed to address the role that NO plays in the etiology of breast cancer.

\section{References}

Al-Ahmadi K, Al-Zahrani A (2013). $\mathrm{NO}_{2}$ and cancer incidence in Saudi Arabia. Int J Environme Res Public Health, 10, 5844-62.

Bonner MR, Han D, Nie J, et al (2005). Breast cancer risk and exposure in early life to polycyclic aromatic hydrocarbons using total suspended particulates as a proxy measure. Cancer Epidemiol Biomarkers Prev, 14, 53-60.

Boothe VL, Boehmer TK, Wendel AM, Yip FY (2014). Residential traffic exposure and childhood leukemia: a systematic review and meta-analysis. Am J Prev Med, 46, 413-422.

Bray F, Ren JS, Masuyer E, Ferlay J (2013). Global estimates of cancer prevalence for 27 sites in the adult population in 2008. International journal of cancer. J Int Du Cancer, 132, 1133-45.

Castano-Vinyals G, Cantor K.P, Malats, N, et al (2008). Air pollution and risk of urinary bladder cancer in a case-control study in Spain. Occup Environ Med, 65, 56-60. 


\section{Aliasghar Keramatinia et al}

Chen F, Bina W (2012a). Correlation of white female breast cancer incidence trends with nitrogen dioxide emission levels and motor vehicle density patterns. Breast Cancer Res Treat, 132, 327-33.

Chen F, Bina WF (2012b). Correlation of white female breast cancer incidence trends with nitrogen dioxide emission levels and motor vehicle density patterns. Breast Cancer Res Treat, 132, 327-33.

Chen X, Wang Y (2008). Tracking of blood pressure from childhood to adulthood: a systematic review and metaregression analysis. Circula, 117, 3171-80.

Cho GJ, Park HT, Shin JH, et al (2010). Age at menarche in a Korean population: secular trends and influencing factors. Eur J Pediat, 169, 89-94.

Crouse DL, Goldberg MS, Ross NA, Chen H, Labreche F (2010). Postmenopausal breast cancer is associated with exposure to traffic-related air pollution in Montreal, Canada: a casecontrol study. Environ Health Perspect, 118, 1578-83.

Donner A, Rosner B, (1980). On inferences concerning a common correlation coefficient. Appl Statist, 29, 69-72.

Ferlay J,Autier P, Boniol M, et al (2007). Estimates of the cancer incidence and mortality in Europe in 2006. Ann Oncol, 18, 581-92.

Gerber B, Muller H, Reimer T, Krause A, Friese K (2003). Nutrition and lifestyle factors on the risk of developing breast cancer. Breast Cancer Res Treat, 79, 265-76.

Hamra GB, Guha N, Cohen A, et al (2014). Outdoor particulate matter exposure and lung cancer: a systematic review and meta-analysis. Environ Health Perspect, 122, 906-11

Hirabayashi Y, Marugame T (2009). Comparison of time trends in ovary cancer mortality (1990-2006) in the world, from the WHO Mortality Database. Jap J Clin Oncol, 39, 860-1.

Hung LJ, Chan TF, Wu CH, Chiu HF, Yang CY, (2012). Traffic air pollution and risk of death from ovarian cancer in Taiwan: fine particulate matter (PM2.5) as a proxy marker.J Toxicol Environ Health A, 75, 174-82.

Iwasaki M, Mameri CP, Hamada GS, Tsugane S (2008). Secular trends in cancer mortality among Japanese immigrants in the state of Sao Paulo, Brazil, 1979-2001. Eur J Cancer Prev, 17, 1-8.

Lewtas, J, 2007. Air pollution combustion emissions: characterization of causative agents and mechanisms associated with cancer, reproductive, and cardiovascular effects. Mutat Res, 636, 95-133.

McTiernan A (2003). Behavioral risk factors in breast cancer: can risk be modified? Oncologist, 8, 326-334.

Parent ME, Goldberg MS, Crouse DL, et al (2013). Trafficrelated air pollution and prostate cancer risk: a case-control study in Montreal, Canada. Occup Environ Med, 70, 511518.

Raaschou-Nielsen, O, Andersen, Z.J, Hvidberg, M, et al (2011a). Air pollution from traffic and cancer incidence: a Danish cohort study. Environ Health, 10, 67.

Raaschou-Nielsen O, Andersen ZJ, Hvidberg M, et al (2011b). Air pollution from traffic and cancer incidence: A Danish cohort study. Environ Health, 19, 10, 67

Shimizu H, Ross RK, Bernstein L, et al (1991). Cancers of the prostate and breast among Japanese and white immigrants in Los Angeles County. Br J Cancer, 63, 963-6.

Stroup DF, Berlin JA, Morton SC, et al (2000). Meta-analysis of observational studies in epidemiology: a proposal for reporting. Meta-analysis of observational studies in epidemiology (MOOSE) group. JAMA, 283, 2008-12.

Tong J, Qin L, Cao Y, et al (2012). Environmental radon exposure and childhood leukemia. J Toxicol Environ Health B Crit Rev, 15, 332-47

Tsugane S, de Souza JM, Costa ML, et al (1990). Cancer incidence rates among Japanese immigrants in the city of Sao Paulo, Brazil, 1969-78. Cancer Causes Control, 1, 189-93. Wei, Y, Davis, J, Bina, W, (2012). Ambient air pollution is associated with the increased incidence of breast cancer in US. Int J Environ Health Res, 22, 12-21

Wink DA, Laval J, (1994). The Fpg protein, a DNA repair enzyme, is inhibited by the biomediator nitric oxide in vitro and in vivo. Carcinogenesis, 15, 2125-9.

Xu W, Liu LZ, Loizidou M, Ahmed M, Charles IG (2002). The role of nitric oxide in cancer. Cell Res, 12, 311-20.

Youlden DR, Cramb SM, Dunn NA, et al (2012). The descriptive epidemiology of female breast cancer: an international comparison of screening, incidence, survival and mortality. Cancer Epidemiol, 36, 237-48. 